\title{
Management of Brown Spot of Rice (Oryza sativa L.) Caused by Bipolaris oryzae by Bio-Control Agents
}

\author{
Vishal Gupta*, Naveed Shamas, V.K. Razdan, Seethiya Mahajan, \\ Kausar Fatima, Satish Sharm and P.K. Rai
}

Sher-e-Kashmir University of Agricultural Sciences and Technology of Jammu, Chatha 180 009, Jатmu \& Kashmir, India

*Corresponding author

\section{A B S T R A C T}

Keywords

Brown spot,

Biopolaris oryzae,

Bio-control agents,

Management, Severity

Article Info

Accepted:

28 March 2018

Available Online:

10 April 2018
Under laboratory conditions using dual culture techniques, bio-control agents (Trichoderma viride, T. harzianum, Pseudomonas fluorescens and Bacillus subtilis) were tested against Bipolaris oryzae the causal organism of brown spot of rice. Maximum inhibition (65.33\%) of mycelial growth of B. oryzae was caused by $T$. harzianum, followed by $T$. viride $(57.76 \%)$ and $P$. flourescens (32.68\%). Under field conditions three rice varieties, Basmati-370, Jaya and PC-19, were used to test the bio-control agents, $T$. viride, T. harzianum and $P$. fluorescens each at $1 \times 10^{9} \mathrm{cfu} / \mathrm{ml}$ concentration. The foliar application of $T$. harzianum exhibited maximum disease reduction $(64.00 \%)$ and also resulted in increased yield in PC-19 (8.00\%) as compare to their respective control.

\section{Introduction}

Brown spot of rice caused by Bipolaris oryzae Subr. and Jain (teleomorph=Cochliobolus miyabeanus) is an important disease of rice throughout the world (Ou, 1985; Savary et al., 2000a), and is responsible for the reduction of 26 to 52 per cent gain in yield (Chakrabarti, 2001). The disease is known to occur in resource poor farmers' fields where there is deficiency of water supply and nitrogenous fertilizers (Zadoks, 1974). In India, the disease was reported to cause Bengal Famine in 1942 with 50-90 per cent in yield loss
(Padmanabhan, 1973). The disease has been reported to occur in all the rice growing countries including Japan, China, Burma, Sri Lanka, Bangladesh, Iran, Africa, South America, Russia, India, North America, Philippines, Saudi Arabia, Australia, Malaya and Thailand (Gangopadhyay, 1983; Ou, 1985; Khalili et al., 2012). The disease is responsible for reduction in leaf area index (LAI), early senescence of the diseased plants, reduction in number of tillers, reduction in shoot elongation and lowered quality and weight of individual grains (Vidhyasekharan et al., 1973; Klomp, 1977). Initiation of the 
symptoms appears as minute spots on leaves which may reach upto $1 \mathrm{~cm}$ or more in length. Similar symptoms also appear on leaf sheaths and coleoptiles. The affected nursery can often be recognized from a distance by scorched appearance due to the death of the seedlings. Fungicides, such as iprodione, propiconazole, azoxystrobin, trifloxystrobin, and carbendazim (Moletti et al., 2000; Cortesi and Giuditta, 2003; Mandal and Jha, 2008) have been reported as an effective means to manage the disease. Inspite of the availability of chemicals for the effective management of brown spot disease, continuous, inappropriate and indiscriminate use of chemicals is known to cause undesirable effects such as residual toxicity, development of chemical resistance, environmental pollution, health hazards to humans and animals and increased expenditure for plant protection. Therefore, application of beneficial microbes for the management of plant diseases has emerged as a viable alternative in the recent past. Keeping in view the economic value of the crop and extensive damage caused by brown spot of rice, the present study was undertaken to evaluate different biocontrol agents for the management of brown spot of rice.

\section{Materials and Methods}

In vitro evaluation of biocontrol agents against Bipolaris oryzae

The bio-control agents viz., Trichoderma harzianum, T. viride, Bacillus subtilis and Pseudomonas fluorescens were tested on Potato Dextrose Agar against the $B$. oryzae by dual culture technique (Dennis and Webster, 1971). The experiment was laid in Completely Randomized Design (CRD) with three replications.

The per cent inhibition of the mycelial growth of the pathogen was calculated using the following formula (Vincent, 1947).
Radial growth in control (mm) -

Radial growth in treatment $(\mathrm{mm})$

Inhibition $(\%)=$

Radial growth in control (mm)

\section{Effect of foliar application of bio-control agents on the severity of brown spot of rice}

Rice varieties, Basmati-370, Jaya and PC-19 were selected for evaluation of biocontrol agents. The seeds of the selected rice varieties were obtained for the Division of Plant Breeding and Genetics SKUAST-J, Chatha, Jammu. The field experiment was laid out in factorial randomized block design with three replications during kharif cropping season for two consecutive years having plot size of $3 x$ $2.5 \mathrm{~m}^{2}$ consisting of 15 rows, each $2.0 \mathrm{~m}$ long and $22.5 \mathrm{~cm}$ apart. Spraying of bio control agents $T$. viride and $T$. harzianum each at $@ 1 \times 10^{8} \mathrm{cfu} / \mathrm{ml}$ and P. flourescens@ $1 \times 10^{8}$ $\mathrm{cfu} / \mathrm{ml}$ were done in the month of August after the appearance of symptoms. Observations regarding disease severity were recorded periodically and yield/plot was calculated at the time of harvesting of crop. Data was statistically analysed by using OP software.

\section{Results and Discussion}

\section{In-vitro evaluation of bio-control agents against Bipolaris oryzae}

The data presented in the Table 1 reveal that among the different bio-control agents tested against Bipolaris oryzae, T.harzianum was most effective with the inhibition of mycelial radial growth of 65.33 per cent, followed by $T$. viride and P. flourescens (57.76 and $32.68 \%$, respectively). The least effective was $B$. subtilus with the per cent inhibition of 26.84 . Amin et al., (2010) had also observed that $T$. harzianum (Th-1), T. viride (Tv-1) and $T$. viride (Tv-2) were significantly effective in reducing the mycelial growth of $B$. oryzae by $37.16,36.75$ and 36.21 per cent, respectively. 
Table.1 Evaluation of bio-control agents against Bipolaris oryzae causing brown spot of rice

\begin{tabular}{|l|}
\hline Bio-control agent \\
\hline Trichodermaharzianum \\
\hline Trichodermaviride \\
\hline Pseudomonas flourescens \\
\hline Bacillus subtilus \\
\hline Control \\
\hline S.E( \pm$)$ \\
\hline C.D. $(p=0.05)$ \\
\hline
\end{tabular}

\section{Bipolaris oryzae}

\begin{tabular}{|c|c|}
\hline Radial growth of mycelium (mm) & Per cent inhibition \\
\hline 29.72 & 65.33 \\
\hline 36.21 & 57.76 \\
\hline 57.72 & 32.68 \\
\hline 62.50 & 26.84 \\
\hline 85.75 & 0.00 \\
\hline \multicolumn{2}{|l|}{1.27} \\
\hline \multicolumn{2}{|l|}{3.75} \\
\hline
\end{tabular}

Table.2 Effect of foliar application of bio-control agents on the severity of brown spot of rice and yield

\begin{tabular}{|c|c|c|c|c|c|c|c|c|}
\hline \multirow[t]{2}{*}{ Variety } & \multicolumn{4}{|c|}{ Mean Disease Severity (\%) } & \multicolumn{4}{|c|}{ Mean Yield (q/ha) } \\
\hline & Control & Th & $\mathbf{T v}$ & Pf & Control & Th & $\mathbf{T v}$ & Pf \\
\hline Basmati-370 & 42.46 & 16.54 & 18.05 & 21.69 & 22.87 & 25.81 & 24.36 & 23.67 \\
\hline Jaya & 20.30 & 9.47 & 13.40 & 13.78 & 36.93 & 39.72 & 38.29 & 37.41 \\
\hline PC-19 & 21.35 & 7.78 & 9.91 & 10.08 & 34.84 & 42.00 & 39.82 & 37.96 \\
\hline $\mathrm{CD}(\mathrm{P}=0.05)$ & \multicolumn{4}{|c|}{$\begin{array}{l}\text { Bio control agents } 4.6 \\
\text { Varieties } 2.7 \\
\text { Interaction }(\mathrm{B} * \mathrm{~V}) 8.07\end{array}$} & \multicolumn{4}{|c|}{$\begin{array}{l}\text { Bio control agents } 1.08 \\
\text { Varieties } 1.17 \\
\text { Interaction }(B * V) 2.41\end{array}$} \\
\hline
\end{tabular}

Th: Trichoderma harzianum

Tv: Trichoderma viride

Pf: Pseudomonas fluorescens

Fig.1 Effect of bio-control agents on per cent reduction of severity of brown spot of rice

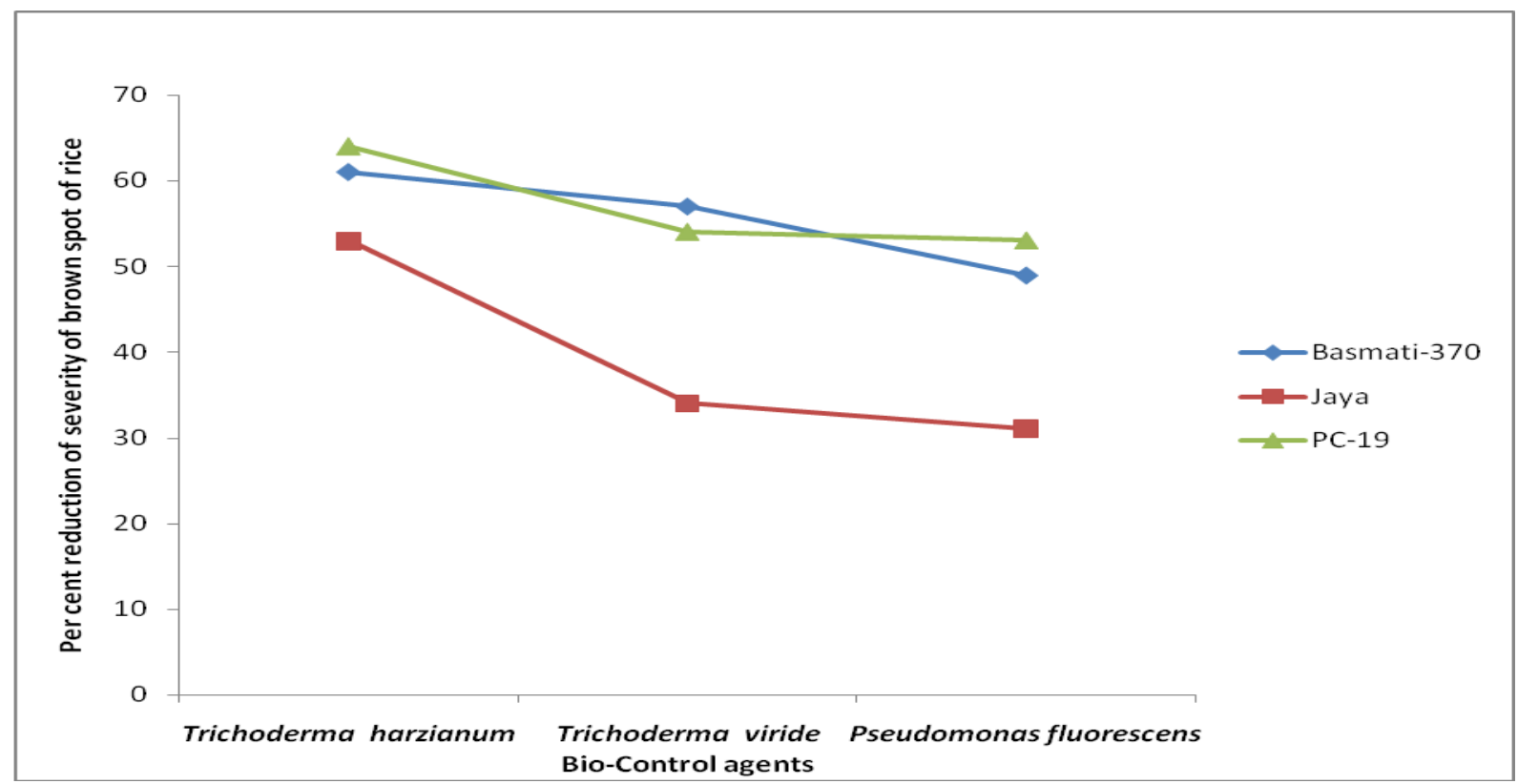


Fig.2 Effect of bio-control agents on per cent increase in yield of rice

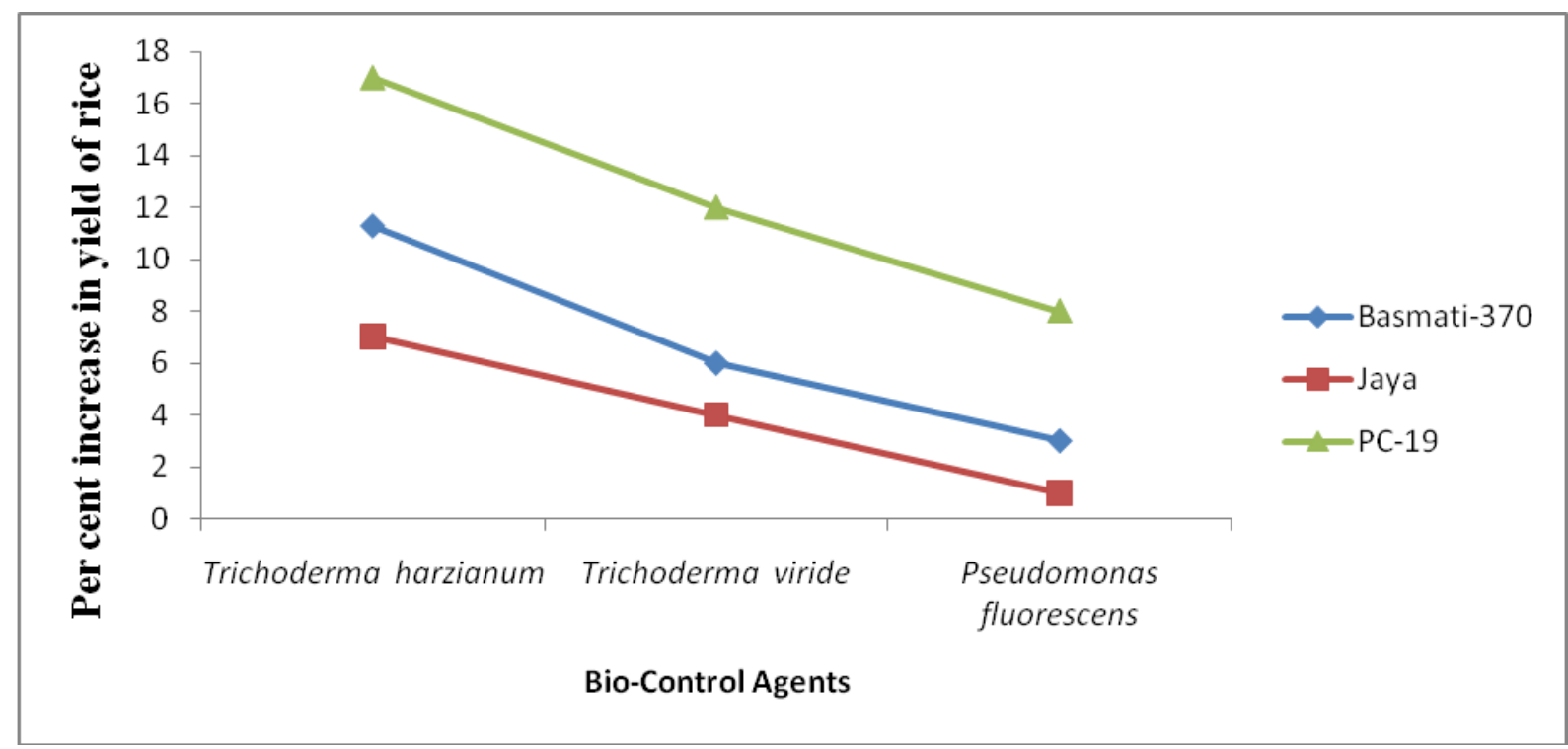

Trichoderma species are known to produce a large number of allelopathic fungal exudates such as antibiotics, peptides, cyclic polypeptides, volatile and non-volatile compounds that suppress the mycelial growth of the plant pathogens (Angelica et al., 2001; Vinale et al., 2005; Harish et al., 2008).

\section{Effect of foliar application ofbio-control agents on the severity of brown spot of rice}

The data depicts that among the three rice test varieties the mean brown spot severity ranged from 21.35 to 42.46 per cent in control plots (Table 2). In Basmati-370, the bio-control agent, $T$. harzianum and $T$. viride exhibited maximum control of brown spot, showing 16.64 and 18.00 per cent mean disease severity, respectively, which was followed by $P$. flourescens with mean disease severity of 21.69 per cent. In the variety Jaya also, $T$. harzianum and $T$. viride exhibited maximum control $(9.47$ and $13.40 \%$ disease severity, respectively), followed by $P$. flourescens having diseases severity of 13.78 per cent. Application of $T$. harzianum and $T$. viride were again most effective in variety PC-19 exhibiting maximum disease control with
7.78 and 9.20 per cent mean disease severity, respectively, followed by $P$. flourescens $(10.08 \%)$. The maximum per cent reduction of $61.00,53.00$ and 64.00 in the brown spot severity was observed with the application of T. harzianum in Basmati-370, Jaya and PC19, respectively (Fig. 1). Kumawat et al., (2008) also found that pre-application of spore suspension of $T$. harzianum and $T$. viride reduced the infection of $B$. oryzae, which was attributed to increased level of total soluble protein and total phenol contents. Two strains of $T$. harzianum were also reported to control the disease in Iran (Khalili et al., 2012). Isolates of fluorescent Pseudomonas from soil have been reported to reduce the fungal growth and brown spot incidence (Ray et al., 1990).

\section{Effect of foliar application of bio-control agents on the yield of rice}

The data presented in the Table 2 further reveal that in rice variety Basmati-370, the application of $T$. harzianum resulted in maximum yield of $25.81 \mathrm{q} / \mathrm{ha}$ which was followed by the application of $T$. viride 24.36q/ha while, P. flourescens showed the 
minimum yield of $23.67 \mathrm{q} / \mathrm{ha}$. The untreated plots in Basmati-370 showed a yield of $22.87 q / h a$. In the variety Jaya, the maximum yield (39.72q/ha) was recorded with application of $T$. harzianum, followed by $T$. viride $(38.29 \mathrm{q} / \mathrm{ha})$, whereas, the minimum increase in yield was observed by $P$. fluorescens (37.41q/ha) as against the untreated plots which showed a yield of $36.87 \mathrm{q} / \mathrm{ha}$. In PC-19 the maximum increase in the yield was shown by $T$. harzianum (42.00q/ha) followed by $T$. viride $(39.82 \mathrm{q} / \mathrm{ha})$, whereas, the minimum increase in yield was shown by $P$. fluorescens $(37.96 \mathrm{q} / \mathrm{ha})$ as against the untreated plots which showed a yield of $34.65 \mathrm{q} / \mathrm{ha}$. Maximum per cent enhancement in yield of 11.30, 7.00 and 17.00 were recorded by foliar application of $T$. harzianum in Basmati-370, Jaya and PC-19, respectively (Fig. 2). Foliar application of $T$. harzianum has been shown to reduce the disease intensity and significantly improve grain yield, total grain carbohydrates and proteins in addition to a significant improvement in the total photosynthetic pigment in the rice leaves (Abdel-Fattah et al., 2007). Baker (1988) attributed the plant growth response induced by Trichoderma species due to the production of a growth regulating factor and induction of systemic response in the host.

\section{References}

Abdel-Fattah, G.M., Shabana, Y.M., Ismail, A.E. and Rashad, Y.M. 2007. Trichoderma harzianum: a biocontrol agent against Bipolaris oryzae. Mycopathologia. 164: 81-89.

Amin, F., Razdan, V. K., Mohiddin, F. A., Bhat, K. A. and Sheikh, P. A. 2010. Effect of volatile metabolites of Trichoderma species against seven fungal plant pathogens in-vitro. Journal of Phytology. 2(10): 34-37.
Angelica, M., Barbosa, G., Rehn, K. G., Menezes, M. and Mariano, R. R. 2001. Antagonism of Trichoderma species on Cladosporium Herbarium and their enzymatic characterization. Brazilian Journal of Microbiology. 32: 98-104.

Baker, R. 1988. Trichoderma species as plantgrowth stimulants, CRC. Critical Review of Biotechnology. 7(2): 97-106.

Chakrabarti, N. K. (2001). Epidemiology and disease management of brown spot of rice in India. In: Major Fungal Disease of Rice: Recent Advances. Kluwer Academic Publishers. pp. 293-306.

Cortesi, P. and Giuditta, L. 2005. Epidemics and disease management of rice brown spot in Italy. Informatore Fitopatologico. 53(2): 41-51.

Dennis, C. and Webster, J. 1971. Antagonistic properties of species group of Trichoderma I. Production of nonvolatile antibiotics. Transaction of the British Mycological Society. 57: 2539.

Gangopadhyay, S. 1983. Current concepts on Fungal Diseases of Rice. Today and Tomorrow's Printers \& Publishers, New Delhi, 349 pp.

Harish, S., Duraiswamy, S., Ramalingam, R., Ebenezar, E.G. and Seetharaman, K. 2008. Use of plant extracts and biocontrol agents for the management of brown spot disease in rice. Biocontrol. 53: 555-567.

Khalili, E., Sadravi, M., Naeimi, S. and Khosravi, V. 2012. Biological control of rice brown spot with native isolates of three Trichoderma species. Brazilian Journal of Microbiology. 43: 297-305.

Klomp, A. O. 1977. Early senescence of rice and Deschlera oryzae in Wageningen polder. Wageningen: Surinam Agricultural Research Report. No 859.

Kumawat, G. L. 2006. Effect of Trichoderma on Drechslera oryzae and its role in defence against brown leaf spot of 
paddy. M.Sc. Thesis. C. S. A. University of Agriculture and Technology, Kanpur, India.

Mandal, S. K. and Jha, V. B. 2008. Management of foliar disease of rice through fungicides. Annals of Plant Protection Sciences. 16: 523-525.

Moletti, M., Giudici, M. L. and Villa, B. 2000. Rice Akiochi-brown spot disease in Italy: agronomic and chemical control. Informatore Fitopatologico. 46: 41-46.

Ou, S. H. 1985. Rice disease (2nd ed.). Kew: Commonwealth Mycological Institute. $380 \mathrm{pp}$.

Padmanabhan, S. Y. 1973. The great Bengal Famine. Annual Review of Phytopathology. 11: 11-26

Ray, S., Ghosh, M. and Mukharjee, N. 1990. Fluorescent pseudomonads for plant disease control. Journal of Mycopathological Research. 28: 135140.
Savary, S., Willocquet, L., Elazegui, F. A., Teng, P. S., Du, P. V., Zhu, D. 2000a. Rice pest constraints in tropical Asia: characterization of injury profiles in relation to production situations. Plant Disease. 84: 341-356.

Vidhyasekharan, P., Ramadoss, N., and Srinivasalu, N. 1973. Quantitative and qualitative losses in paddy due to Helminthosporiose epidemic. Indian Phytopathology. 26: 479-484.

Vinale, F., Marra, R., Scala, F., Lorito, M., Ghisalberti, E. L. and Sivasithampram, K. 2005. Secondary metabolites produced by two commercial strains of Trichoderma harzianum. Journal of Plant Pathology. 87(4): 267-309.

Vincent, J. M. 1947. Distortion of fungal hyphae in the presence of certain inhibitors. Nature, 159- 350.

Zadoks, J. C. 1974. The role of epidemiology in modern Phytopathology. Phytopathology. 64: 918-929.

\section{How to cite this article:}

Vishal Gupta, Naveed Shamas, V.K. Razdan, Seethiya Mahajan, Kausar Fatima, Satish Sharm and Rai, P.K. 2018. Management of Brown Spot of Rice (Oryza sativa L.) Caused by Bipolaris oryzae by Bio-Control Agents. Int.J.Curr.Microbiol.App.Sci. 7(04): 3472-3477. doi: https://doi.org/10.20546/ijcmas.2018.704.393 